\title{
APPLICATION OF PROFESSIONAL JUDGEMENT BY RUSSIAN AND EUROPEAN COMPANIES IN DETERMINING THE SCOPE OF CONSOLIDATION
}

\author{
Natalia Generalova \\ Saint-Petersburg State University, Russia \\ Ekaterina Popova \\ Saint-Petersburg State University, Russia
}

\begin{abstract}
It is within the field of the accountant's professional substantial judgment application to determine whether the investor controls an investee. The research based on 237 consolidated financial statements in accordance with IFRS of Russian and European companies was aimed at revealing and comparing the impact of accountant's judgement on determination of the scope of consolidation. As a result, it has been found out that a considerable proportion of both Russian (40.0\%) and European (43.93\%) companies are governed by the judgement in determination of the control over an investee. IFRS 10 "Consolidated Financial Statements" contains principles of determination the existence of control de facto. Yet, the concept of "de facto" control can be interpreted by different accountants in various ways. The range of an accountant's interpretation of control is influenced (i.e. may "expand" or "taper") by companies's size and industry, local laws and other circumstances. Furthermore, this paper reveals factors owing to which the companies were entitled with the right to control the investee in accordance with "de facto" control in the absence of "de jure" control; also factors of the absence of "de facto" control with the majority voting rights in the subsidiary (in the presence of "de jure" control).
\end{abstract}

Keywords: consolidated financial statements, IFRS, professional judgement, de facto control

JEL code: M 410, M 400.

"Yet, the world is enormous, and the same judgements can be interpreted in it in different ways. Depending on how an accountant would interpret them, the financial results may vary, as well as the tax payments and the owners' capital".

Y. V. Sokolov, T. O. Terentyeva

\section{Introduction}

Because of equal accessibility, the presence of uniformity principles and the presence of careful thought-out principles, financial statements have the advantages in comparison with other source of information about the company. Consolidated financial statements contain information about the group of companies which are "closely interacting in business activity". The "closeness of interaction" is at large defined by the existing rules and principles which, in turn, are being interpreted by the human factor, i.e. an accountant. R. Mattessich emphasized that "there has always existed certain tension between the practice of accounting and academic accounting" (Mattessich, p. 181). Professor Y. V. Sokolov wrote that "Accounting data is not the reflection of a business process, but an extent of our feasible (potential) influence on it" (Sokolov, Y. V., 2014, p. 40). Having analysed consolidated financial statements of Russian and European companies in accordance with IFRS, the authors have drawn a conclusion that there is a substantial impact of an accountant's professional judgement on determining the existence of the investor's control over their investee. The 
scope of consolidation is determined by definition of the concept of "control" according to IFRS 10 "Consolidated Financial Statements". In turn, the interpretation of control is dependent on the accountant's professional judgement.

The issue of the professional judgement application in preparation of consolidated financial statements is deemed topical nowadays. The idea of cross-country comparison of the application of professional judgement has been put forward by both Russian and Europen authors. Some ideas contained in such publications have been taken into consideration to create the approach to the present study (for example, see Filip, A., 2015; Generalova, N. Sokolova, N., Popova, E. 2016; Ca ta lin Nicolae Albu and others, 2014).

The undertaken research study was focused on the issue of the cross-coupling effect of professional judgement and control over the investee in the course of the preparation of consolidated financial statements in accordance with IFRS by Russian and European companies. This present paper serves as a continuation of a previously conducted research the results of which were based on the data from Russian companies, and were reported at the conference in Prague "IFRS Global Rules \& Local Use 2016" (http://car.aauni.edu/conferences/ifrs-2016-conference/), see (Generalova, N., Popova, E., 2016).

For the present research study it is suggested the following hypotheses:

H1. Determination of the scope of consolidation based in IFRS on the concept of "control" (IFRS 10, p. 7-9, Appendix B), is at large dependent on the accountant's professional judgement.

H2. In view of inter- and cross-country, and national accounting peculiarities the accountant will make judgement in various ways, also in connection with determination of the existence of control over an investee.

H3. The company business profile (industry appurtenance) places a real impact on the accountant's judgement in terms of determining the de facto control.

The research aim is to compare the distinctions in application of the professional judgement by Russian and European companies for determination of control over an investee; also to reveal grounds for the power to control de facto.

\section{Research methodology}

Two groups for the sampling study

Two groups of companies were studied under the research, i.e. Russian companies (hereinafter, "GRus") and European (mainly, the Estonian companies) companies (hereinafter, "GEu"). The sample group "GRus" consisit of 130 Russian companies, and 107 companies for group "GEu" were chosen from the following states: Estonia, Latvia, Luthuania, Finland, Norway, Denmark, Poland, Switzerland, the Netherlands, and Belgium. Thus, the total of 237 companies and their consolidated financial statements were under the research.

The rating of 600 largest Russian companies in 2015 (RAEX 600) was used for sample selection of "GRus" (http://www.raexpert.ru/rankingtable/top_companies/2015/main/).

Sampling companies belonging to "GEu" was carried out by three rankings: Ranking of 100 largest Estonian companies "MAI100 2014: Eesti suurima väärtusega ettevõtted" (http://www.maibaltics.com/files/filemanager/files/MAIB100/MAI100_2014_est.pdf);

Ranking of 50 largest Baltic companies "Top-50 Baltic companies 2015" (http://www.coface.at/en/News-Publications/Publications/Coface-Baltic-Top-50-2015- 
edition); and Ranking Forbes 2016 "The World's Biggest Public Companies" (http://www.forbes.com/global2000/list/\#tab:overall). Out of ranking "MAI100 2014", 47 companies $(43.93 \%$ of total sampled companies) have been selected for research. 60 companies have been selected from ranking "Top-50 Baltic companies 2015" and Ranking Forbes 2016, including companies belonging to: Sweden (16 companies), the Netherlands (12 companies), Denmark (9 companies), Belgium (8 companies), Norway (6 companies), Finland (5 companies), Poland (2 companies), Latvia (1 company), Lithuania (1 company).

\section{Assumptions applied in sampling and limitations}

Out of 600 largest Russian companies only 125 corporations had prepared the consolidated financial statements in accordance with IFRS. These 125 Russian Groups were included into the sample. Besides, 5 companies were additionally studied. These companies were not included into rating RAEX 600 but they do consolidated financial statements according to IFRS.

The research was based on the analysis of the data shown in consolidated financial statements under IFRS. The consolidated financial statements for 2015 were of the research primary interest. There was an insignificant number of companies (mainly in the "GRus") who had not published their consolidated financial statements by the time of this research.

\section{Research Results}

IFRS 10 "Consolidated Financial Statements", published in May 2011, contains a revised, or rather an elaborated definition of control and is supplemented with a detailed guide to determine the existence of the investor's control over their investee. The principles specified in IFRS 10 incorporated the ideas which were previously contained in IAS 27 "Consolidated and Separate Financial Statements", in SIC 12 "Consolidation - Special Purpose Entities", and also employed the ideas downloaded in US GAAP. Therefore, IFRS 10, i.e. a uniform international standard for consolidation, presents a single integrated model for control which is applicable to companies of different types. Nonetheless, even with the availability of a single integrated model for control, there is still a necessity to take into consideration its application features in concrete circumstances.

IAS 1 "Presentation of Financial Statements" requires disclosure of judgements that the company management has made in the process of applying the entity's accounting policies and estimations. Such information should be disclosed along with significant accounting policies or other reference notes (IAS 1, par. 122 and 125). These sections of financial statements have been analyzed to determine the proportin of companies that disclosure information about the assumptions regarding whether the investor controls the investee.

The following parts of consolidated statements were under the study, i.e. "The list of subsidiaries" and "Key judgement and estimates", as well as the principles of accounting policy in respect to consolidation in section "Principal accounting policies". The analysis of the section "The List of subsidiaries" showed that not all the companies which dealt with consolidation following the principle of the de facto control existence (in other words, in the absence of the $50 \%$ majority of voting rights), showed this fact in "Key judgement and estimates". We suppose that for such companies the effect from the inclusion of such subsidiary into the group is not just so important as may be other issues in connection with which the judgement is requisite.

\section{Application of judgement in determining the existence of control by Russian companies}

Judgement and Consolidation. The sampled 130 companies showed that $\mathbf{1 7 . 6 9 \%}$ (23 companies) of them specified the scope of consolidation or control over the investee in the 
"Key judgement and estimates". The analysis of "The list of subsidiaries" revealed that 40.00\% of the companies showed in their statements the business results of their subsidiaries which were consolidated considering the existence of the factual control (i.e. in the absence of ownership in the them of more than half of the voting rights, or else they were not consolidated in the presence of over $50 \%$ of the voting rights).

Grounds for the power to control de facto. The analyzed reasons by which the companies determined the existence of the de facto control over the investee are ranged by their frequency application in Table 1. The "structured entities" was classified as a separate group. $40.38 \%$ of companies consolidated the structured entities. Also, a substantial number of companies $(13.46 \%)$ believe that they control their investees by reason that there is a wide spread of non-owned by them shares among other non-controlling shareholders. The next in importance factor providing for the control is an agreement with the other investors that the parent company should have the control. $4.69 \%$ of parent companies make agreements with the other investors in such way that the control belongs to them.

Substantial influence of the decision on consolidation of structured entities. Consolidation of structured entities is specially emphasized among other factors of consolidation in Table 1. During the research it was noticed that decision on inclusion/non-inclusion of structured entities into the scope of consolidation has a substantial influence on the consolidated financial statements of the group. Such structured entities are specially established for the needs of the group and, as a general rule, serve a source of external financing for Russian companies. Structured entities are mostly used for the business of financial sector companies. Among $40.38 \%$ of the companies (see, Table 1) which use structured entities, only two companies do not belong to the financial sector. These are "Dixy Group" (a retail food store chain) and "Russian Railways" Group (railway transportations).

Let us show the extent of influence of the decision to include a structured entity into the scope of consolidation in the context of "Russian Railways" JSC. In their statements for 2015 Russian Railways JSC showed consolidation of a structured entity RZD Capital P.L.C. and emphasized that "The principal business of RZD Capital P.L.C. is the issue of debt securities for the sole purpose of providing loans to the Company". Our analysis of the Notes "Longterm and short-term loans" of consolidated financial statements of "Russian Railways Group" showed that the proportion of long-term liabilities of the structured entity was $54.49 \%$ of the long-term liabilities of the Group.

Out of all analyzed Russian companies only one indicated the quantitative impact of the consolidation of structured entities. It was PJSB "TransCapitalBank". The consolidated financial statements for 2015 of PJSB "TransCapitalBank"contain the following information, "Non-consolidation of the special purpose entities would decrease the Group's total consolidated assets by RR 2442228 thousand (2014: RR 3269347 thousand). The impact on the consolidated profit after tax would be an increase by RR 30603 thousand (2014: a decrease by RR 100390 thousand). " (CFS of PJSB “TransCapitalBank", 2015, pg. 18).

\section{Application of judgement in determining the existence of control by European companies}

Judgement and Consolidation. The sampled 107 European companies showed that $\mathbf{1 4 . 9 5 \%}$ of them specified the scope of consolidation or control over the investee in the "Key judgement and estimates". $\mathbf{3 5 . 5 1 \%}$ of the European companies showed in their consolidated statements the business results of their subsidiaries which were consolidated considering the existence of the factual control (i.e. in the absence of ownership in them of more than half of the voting rights, or else they were not consolidated in the presence of over 50\% of the votes). $\mathbf{1 4 . 0 2 \%}$ of the European companies did not show the business results of the companies in their consolidated statements in the absence of de facto control or due to its insignificance. 
Grounds for the power to control de facto. Table 1 shows the comparative analysis of reasons owing to which subsidiaries of Russian and European groups of companies (in the absence of the dominancy of voting rights in them) were included into their group's consolidated financial statements. The biggest part of the European companies consolidated indirect subsidiary entities in the absence of their indirect shareholding in them of the voting majority, i.e. $26.53 \%$. Also, a considerable part of European companies had the power to manage relevant activities under the agreements with the other investors, i.e. $22.45 \%$ (see, Table 1 column 2). It would be reasonable to point out another characteristic of European companies consolidation which distinguishes them from the Russian companies. 8.16\% of the European companies had the de facto control owing to the provisions of their local legislation. Statements of the Russian companies did not show any direct indication that the control existed owing to the local legislation. The other factors are shown in Table 1.

Table 1. Factors providing the Russian and European companies with the right to control an investee using de facto control, sampled CFSs for 2015

\begin{tabular}{|c|c|c|}
\hline \multirow{2}{*}{$\begin{array}{c}\text { REASON FOR CONSOLIDATION } \\
\text { (factors to determine whether the investor } \\
\text { controls the investee, in the absence of "de } \\
\text { jure" control) }\end{array}$} & \multicolumn{2}{|c|}{ The proportion out of the total sampled companies, $\%$} \\
\hline & EUROPEAN COUNTRIES & RUSSIA \\
\hline 1 & 2 & 3 \\
\hline Indirect Subsidiary & & 15.38 \\
\hline $\begin{array}{l}\text { Contractual arrangement between the } \\
\text { investors }\end{array}$ & 22.45 & 7.69 \\
\hline Overall, the phrase "de facto" control & 16.33 & 5.77 \\
\hline Consolidated structured entity & 12.24 & 40.38 \\
\hline According to local law of country & 8.16 & 0.00 \\
\hline Potential voting rights & 6.12 & 5.77 \\
\hline $\begin{array}{l}\text { The ability to appoint of investee's members } \\
\text { of Board of Directors and establish } \\
\text { management remuneration }\end{array}$ & 4.08 & 3.85 \\
\hline $\begin{array}{l}\text { Wide dispersion of holdings of voting rights } \\
\text { among the other holders }\end{array}$ & 2.05 & 13.46 \\
\hline Call option to purchase $100 \%$ voting share & 2.04 & 3.85 \\
\hline $\begin{array}{l}\text { Investee's voting shares owned by Group's } \\
\text { shareholders }\end{array}$ & 0.00 & 1.93 \\
\hline The presence of a significant debt guarantees & 0.00 & 1.92 \\
\hline Total & 100.00 & 100.00 \\
\hline
\end{tabular}

Source: compiled by the authors on the basis of the conducted research

Comparison of "GRus" and “GEu": professional judgement in determination of the control existence in terms of the companies type of business

While analysing the research data for "GRus" and "GEu", we became convinced in the fairness of hypothesis H1: Determination of the scope of consolidation is at large dependent on the accountant's professional judgement. It is also acknowledged that the influence of professional judgement in this case is substantial, i.e. $40.00 \%$ of Russian and $43.93 \%$ of European companies showed in their statements the results of their subsidiaries' business activities in compliance with de facto control. As long as the proportion is approximately the same (40.00\% and 43.93\%), hypothesis $\mathbf{H 2}$ is contested: inter- and cross-country 
peculiarities have an insufficient impact on the accountant's judgement in respect to the scope of consolidation. A considerable influence for that is the type of the company business (confirmation of hypothesis H3) (see, Table 2).

Table 2. Application of professional judgement by the Russian and Europen groups of companies in determining the scope of the group, sampled CFSs for 2015

\begin{tabular}{|c|c|c|c|c|c|c|}
\hline & \multicolumn{3}{|c|}{ EUROPEAN COUNTRIES } & \multicolumn{3}{|c|}{ RUSSIA } \\
\hline Industry & $\begin{array}{c}\text { The proportion } \\
\text { of companies, } \\
\text { Consolidation, } \\
\%(1)\end{array}$ & $\begin{array}{l}\text { The proportion } \\
\text { of companies, } \\
\text { Judgement, \% } \\
\text { (2) }\end{array}$ & $\begin{array}{c}\text { The average } \\
\text { number of } \\
\text { consolidated } \\
\text { subsidiaries, } \\
\% \text { (3) }\end{array}$ & $\begin{array}{c}\text { The proportion } \\
\text { of companies, } \\
\text { Consolidation, } \\
\%^{(1)}\end{array}$ & $\begin{array}{c}\text { The } \\
\text { proportion of } \\
\text { companies, } \\
\underset{\text { Judgement, \% }}{(2)}\end{array}$ & $\begin{array}{c}\text { The average } \\
\text { number of } \\
\text { consolidated } \\
\text { subsidiaries, } \\
\% \text { (3) }\end{array}$ \\
\hline 1 & 2 & 3 & 4 & 5 & 6 & 7 \\
\hline $\begin{array}{l}\text { Trading and } \\
\text { services }\end{array}$ & 44.83 & 10.34 & 5.01 & 31.25 & 18.75 & 29.43 \\
\hline $\begin{array}{l}\text { Oil and gas, } \\
\text { chemical industry }\end{array}$ & 42.86 & 42.86 & 3.26 & 11.76 & 17.65 & 15.66 \\
\hline $\begin{array}{l}\text { Financial } \\
\text { companies }\end{array}$ & 38.89 & 38.89 & 12.45 & 47.50 & 25.00 & 45.28 \\
\hline $\begin{array}{l}\text { Electric energy } \\
\text { industry }\end{array}$ & 37.50 & 0.00 & 4.48 & 30.00 & 0.00 & 8.17 \\
\hline Transport & 28.57 & 14.29 & 1.30 & 28.57 & 14.29 & 6.93 \\
\hline Construction & 25.00 & 0.00 & 3.18 & 25.00 & 0.00 & 4.26 \\
\hline $\begin{array}{l}\text { Telecommuni- } \\
\text { cation }\end{array}$ & 22.22 & 22.22 & 4.15 & 60.00 & 20.00 & 5.27 \\
\hline $\begin{array}{l}\text { Industrial } \\
\text { production }\end{array}$ & 19.05 & 4.76 & 2.45 & 35.00 & 25.00 & 16.09 \\
\hline $\begin{array}{l}\text { Mechanical } \\
\text { engineering }\end{array}$ & $\mathrm{x}$ & $\mathrm{x}$ & $\mathrm{x}$ & 50.00 & 0.00 & 6.98 \\
\hline $\begin{array}{l}\text { The average of } \\
\text { sample }\end{array}$ & 32.36 & 16.67 & 4.54 & 35.45 & 13.41 & 15.34 \\
\hline
\end{tabular}

Source: compiled by the authors on the basis of the conducted research.

(1) The proportion of the company groups which consolidated entities with the investment share in them less than $50 \%$.

(2) The proportion of the company groups within an industry, which indicated control in the sphere of "Professional judgement".

(3) An average number of subsidiary companies in an industry which might be rolled up and which the group consolidated but has less than $50 \%$ share in them (the proportion of the consolidated companies in compliance with de facto control in the total number of consolidated companies).

Judging from the data of Table 2 which provides a comparative analysis for groups "GRus" and "GEu", the following conclusions can be drawn. (1) European trading and servicing companies are more willing to consolidate in compliance with de facto control (in the absence of more than $50 \%$ of voting rights), whereas in Russia such companies belong to telecommunication and communication industries (compare, columns 2 and 5 in Table 2). (2) Substantial influence of consolidation in compliance with de facto control on the statements on the whole mainly refers to the European companies in oil and chemical industries and to the Russian companies in the financial sector (compare, Table 2, columns 3 and 6). (3) Considering cases of consolidation in compliance with de facto control, each European company on the average consolidated $12.45 \%$ such companies from the total number, and each Russian company $-45.28 \%$ (compare, Table 2, columns 4 and 7).

\section{Conclusion}

The research analysis of the extent to which accountants apply their professional judgement in terms of determination of the scope of consolidation strongly indicate the fairness of the words which belong to Professor Y. V. Sokolov and T. V. Terentyeva and which were cited in the beginning of this paper (Y. V. Sokolov, T. O. Terentyeva, 2001). Communication between the statements' users and the company (with the aid from the accountant who interprets 
information on the company business activity) is "complicated" not only by the subjective character of the judgement made by the accountant and the company management, but also by the specific nature of its perception by the users. E. S. Hendriksen and M. F. van Breda emphasized that "The meaning and significance of the accounting information are dependent on the way it is interpreted by the users of financial statements" (E. S. Hendricksen and M. F. van Breda, 2000). Still, application of the accountant's professional judgement is important for the users' understanding and comparing of the influence of inter- and cross-country, legal and other characteristics emerging in the course of the company business activities in differenr countries. Undoubtedly, the accountant's judgement is supposed to be appropriate and feasible and, what is more, fair. And the characteristic of fairness was especially emphasized by Professor Y. V. Sokolov (Y. V. Sokolov, 2011). The research was carried out and based on 237 consolidated financial statements in accordance with IFRS for 2015. The research selection was comprised of two groups of companies, i.e. "Russian" (130 observations) and "European" companies (107 observations). The major conclusions can be summarized as follows.

The research hypotheses $\mathrm{H} 1$ and $\mathrm{H} 3$ were confirmed, whereas hypothesis $\mathrm{H} 2$ within the framework of the research selection is contested (see explanations in part Comparison of "GRus" and "GEu").

1. The interpretation of de facto control is at large dependent on the accountant's professional judgement. Introduction of the issue of 'determination of the scope of judgement' into "Key judgement and estimates" of consolidated financial statements allows to state that determination of "investor's control over the investee" is an important issue which substantially influences the consolidated financial statements. A considerable part of Russian companies, i.e. $17.69 \%$, referred the issue of determining the scope of consolidation to core judgement. Among European companies the figure for this phenomenon was $14.95 \%$. It would be reasonable to emphasize that special influence on consolidated statements is exercised by the decision on structured entities consolidation. The respective examples of this were given hereinabove.

2. In the course of the research the authors also studied the scope of consolidation of the sampled company groups (see, "The list of subsidiaries"). Within the sampled total $35.51 \%$ of European companies (and 36.98\% of Russian companies) included for the year 2015 into the scope of consolidation companies in which the share participation did not reach $50 \%$ of the voting rights, but which were, however, controlled in view of the de facto control existence. Out of the sampled companies $14.02 \%$ of European companies (and 3.08\% of Russian companies) did not include into their scope of consolidation entities the share participation in which was more than $50 \%$ of the voting rights. Reasons by which made it possible for the companies to include into their scope of consolidation entities in which they did not have the simple majority of the voting rights were also analysed in this paper.

3. The judgement which the accountant makes is partially under the influence of the circumstances which are beyond their control, i.e. type of the company business, country characteristics of doing business and accounting, etc.

Judgement influences the determination whether "de facto" control exists. This influence depends on company size. For instance, Large Russian companies, which are usually controlled by the state, are more inclined to use judgement in the area of non-consolidation (due to the immateriality) rather than consolidation. Medium-sized companies, which rapidly grow and launch IPO, apply judgement to consolidate structures in the absence more half of voting rights. 
Judgement influences the determination whether "de facto" control exists. This influence depends on company business field. Consolidated structured entities, in which parent companies do not have a majority voting rights but can predetermine its activities, are most commonly used by financial companies such as banks and insurance companies.

4. The summary conclusion resultant from s.1 and s.2 herein may read as follows: an accountant's professional judgement in respect to determination of the existence of control over the investee is applied by $\mathbf{4 0 . 0 0 \%}$ of Russian and by $\mathbf{4 3 . 9 3 \%}$ of European companies.

Further research is planned in the following areas. The author feels it important to 1) expand the sampled Foreign companies belonging to such areas as Anglo-American and Asian regions; 2) analyze the dynamics of change in the scope of consolidation based on the sampled companies; compare the results with the key changes in the concept of "control" in IFRS in the course of time (from IAS 31976 to IFRS 10 2013); 3) identify (including through the application of mathematical methods) possible abusive practices arising from the implementation of professional judgement in practical life in derermining whether the investor controls the investee. Such manipulations may appear in order to have an influence on financial statements users.

\section{References}

Albu, C. N., Albu, N., Alexander, D., (2014). When global accounting standards meet the local context - Insights from an emerging economy. Critical Perspectives on Accounting, no. 25, pp. 489-510.

Filip, A., Jeanjean, T., Paugam, L. (2015). Using Real Activities to Avoid Goodwill Impairment Losses: Evidence and Effect on Future Performance. Journal of Business Finance and Accounting, vol. 42, Issue 2-3, pp. 515-554.

Generalova, N., Sokolova, N., Popova, E. (2016). Goodwill impairment versus amortization: Research of practice and the theoretical basis. In: Proceedings of the 27th International Business Information Management Association Conference, Milan, Italy, pp. 1549-1559.

Generalova, N., Popova, E. Assessment of an Accountant's Professional Judgement Influence in Determining the Presence of the Control over an Investee.

Available on-line at www. http://car.aauni.edu/wp-content/uploads/Proceedings-from-theAAU-Conference-IFRS-Prague-2016.pdf (10 October 2016)

Hendriksen, E. S., Michael F. van Breda (2000). Accounting theory, Moscow: Finance and Statistics. (in Russian)

International Accounting Standards Board (2001). IAS 1 "Presentation of Financial Statements". London: International Accounting Standards Board.

International Accounting Standards Board (2011). IFRS 10 "Consolidated Financial Statements". London: International Accounting Standards Board.

Mattessich, R. (2008). Two Hundred Years of Accounting Research: An International Survey of Personalities, Ideas and Publications. Milton: Routledge.

Sokolov, Y. V. (2014). Accounting as a Sum of the Economic Life Facts, Moscow: INFRAM. (Соколов Я. В. Бухгалтерский учет как сумма фактов хозяйственной жизни. - М.: Магистр; ИНФРА-М, 2014.). (in Russian)

Sokolov, Y. V., Sokolov, V. Y. (2011). A History of Accounting. 3rd ed. Moscow: Magistr. (Соколов Я. В., Соколов В. Я. История бухгалтерского учета: учебник. - 3-е изд., перераб. и доп. - М.: Магистр, 2011.) (in Russian) 
Sokolov, Y. V., Terentyeva, T. O. (2001). Professional judgement: Results of the past century. Accounting, no. 12, pp. 53-57. 